\title{
Şehitlik Mosque and the Islamic Cemetery at Columbiadamm: Islam in Public Space
}

\author{
Martin Klapetek (iD) https://orcid.org/0000-0001-9848-7053 \\ Department of Philosophy and Study of Religions \\ University of South Bohemia in České Budějovice \\ klapetek.martin@gmail.com
}

\begin{abstract}
The issue of creating spaces dedicated to religious activities and that of the establishment of particular sections for Muslims at public cemeteries might be viewed as a single one. While researching mosques, one needs to accent the multi-functionality of the premises. The final shape of the interior and the exterior of the buildings can be understood as a result of internal and external influences. In the case of the establishment of cemetery fields, the observation of the processes of expert solutions is important. In both issues the need of community organisation is displayed. Furthermore, the long-term construction of "otherness" in the European public space is in question. The discipline of Comparative Religious studies retains the possibilities to analyse the results of the research of Muslim communities and compare them with other examples (e.g., Jewish communities, small Christian churches or new religious movements). Thus issues concerning Islam can become a part of the wider discourse concerning secularisation and the deprivatisation of religion in Europe. The paper contributes to this discussion by pointing out the interconnection of needs of the Muslim population and manifestation of uniqueness in public space.
\end{abstract}

Keywords: Islam, mosque, cemetery, Germany, Berlin

Słowa kluczowe: islam, meczet, cmentarz, Niemcy, Berlin

\section{Introduction}

The institutionalisation of Islam in Europe has been a long-term process, observable mainly from the twetieth century. This process has been an object of research of various scientific disciplines, such as History, Sociology, Political Science, and Religious studies. Many issues are examined in different disciplines by their own specific methodologies. That leads to the diversity of approaches of researchers. However, the 
research of Islam has been overcoming this scatteredness of approaches due to the publication of compendia, collective monographs, specialised journals, and thematic yearbooks. ${ }^{1}$

The present paper attempts to link up to previous academic debates and emphatically point out the possibility of connecting two issues into one. These issues are the building of representative nostalgic mosques and the administration of public cemeteries dedicated to Muslims. ${ }^{2}$ The text first examines the general conditions of the institutionalisation of the Muslim communities in Germany. It points out that the creation of spaces for regular gatherings as well as the establishment of specialised cemetery fields are expressions of the needs of the communities. Both issues can be also examined as manifestations of "otherness" in public space. General conditions are then applied to the specific example of the Mosque of Martyrs located within the Islamic cemetery at Columbiadamm in Berlin-Neukölln.

The study is a result of research during which the following methods were used: critical analysis of academic literature, non-participant observation, analysis of selfpresentation, photo documentation, and description of location. The text is based on an analysis and comparison of examples from Berlin visited during research visits conducted in 2012 and $2014 .^{3}$

\section{Mosque and cemetery in general context of institutionalisation}

Institutionalisation is a long-term process that results in a creation of network of permanent institutions. The number of permanent residents with specific cultural background have to increase. In some moment this group starts to seem to by stratified into several generations. That is why the dealing with problems ad hoc is insufficient, but the systematic approach is needed. In the case of Muslims in Germany, it was reflected by establishing of large number of Islamic organizations. Some of them operate throughout the whole Germany, others at the state level and another organizations work just locally. On one hand, they are result of needs of local communities. On the other hand, they are influenced by social and political agency of countries of origin of the community members. For contemporary Germany it is typical that the government has not resolved satisfactorily its relationship with major Islamic organizations:

${ }^{1}$ M. Rohe, Der Islam in Deutschland. Eine Bestandsaufnahme, Munich 2016; Everyday Lived Islam in Europa, N.M. Dessing, N. Jeldtoft, J.S. Nielsen, L. Woodhead (eds.), Farnham 2013; Yearbook of Muslims in Europe, O. Scharbrodt, S. Akgönül, A. Alibašić, J.S. Nielsen, E. Račius (eds.), Leiden 2018, vol. 9 .

${ }^{2}$ B. Beinhauer-Köhler, Von der unsichtbaren zur sichtbaren Religion. Räume muslimischer Glaubenspraxis in der Bundesrepublik, "Zeithistorische Forschungen" 2010, vol. 7, no. 3, pp. 408-430.

3 The data was collected during a month-long research stay in Berlin supported by the Czech Ministry of Education, Youth and Sports. I analysed and compared this data with that obtained during a stay in Berlin supported by grant projects of the Czech Science Foundation. I offer my thanks for this support. I also thank the anonymous reviewers for their careful reading of my manuscript and their many insightful comments and suggestions, as well as Karel Pazourek, $\mathrm{PhD}$ for helping with the final version of the text. 
There does not exist any Islamic organization as corporation under public law which operates on national level. This fact complicates their activities in the public space. ${ }^{4}$

For institutionalisation, as well as for many topics, Comparative Religious Studies provides tools to establish more generalised issues comparing specific facts. Focusing on the history and present-day situation in Europe, several examples for comparison are readily available. The research of the institutionalisation of Muslim communities may make use of resources documenting the historical development of Jewish communities ${ }^{5}$ as well as the development of minority Christian communities. In some cases the examples of various groups designated under the umbrella term "New religious movements" by the Sociology of religion can be considered inspirational as well. ${ }^{6}$

One of these issues is the building, decoration, and operation of united spaces designated mainly for regular religious gatherings. A particular space can also serve other basic functions, such as cultural, educational, free-time, healthcare-related, or social. ${ }^{7}$ The multi-functionality of a given space reflects the needs of the community, which can be subject to change in the course of time. Some of them lose their previous purpose, for instance the relevance of sharing job posts lowers in accordance with the strengthening social positions of the members of the community. ${ }^{8}$ Other functions appear only for a limited time. This phenomenon was observable for instance during the 2015 refugee crisis: for several months it was necessary to secure food and accommodation for a high number of people (Graz, Austria). The importance of certain needs grows over time such as broadening the forms and offer of the education of children, teenagers, and adults. Similarly, the same category covers one of the key challenges of the present-day Muslim communities of Europe - the care for seniors coming from a Muslim cultural background. ${ }^{9}$

Another possible realization is the connection of several permanently furnished spaces with respect to their only or prevailing function into one unit within a given building. In such cases we might observe the refurbishment of buildings that were originally built for a different purpose. These can often be found in industrial zones at the outskirts of cities, which presents troubles with transportation for regular

\footnotetext{
${ }^{4}$ R. Chbib, Organisations des Islams in Deutschland. Divärsität, Dynamiken und Sozialformen im Religionsfeld der Muslime, Baden-Baden 2017.

${ }_{5}^{5}$ M. Baumann, Temples, Cupolas, Minarets: Public Space as Contested Terrain in Contemporary Switzerland, "Religio" 2009, vol. 17, no. 2, pp. 152-153; R. Epstein-Mil, M. Richter, Die Synagogen der Schweiz. Bauten zwischen Emanzipation, Assimilation und Akkulturation, Zürich 2008.

${ }^{6}$ R. Stark, How New Religions Succeed: A Theoredical Model, [in:] The Future of New Religious Movements, D.G. Bromley, Ph.E. Hammond (eds.), Macon 1987, pp. 11-27.

${ }^{7}$ M. Klapetek, Synagoga, kostel, mešita... Architektura jako téma pro religionistiku, "Pantheon" 2013, vol. 8, no. 2, pp. 56-59.

${ }^{8}$ Such posts can be found on notice boards in the entrances of mosques, together with posts on other activities of the community. Office of the mosque can be also used for other activities, for example education.

${ }^{9}$ M. Klapetek, Umírání a smrt: Realizace náboženských pravidel v nemuslimském prostředí, [in:] Smrt, hroby a záhrobí v islámu. Posledni věci člověka pohledem muslimských pramenů, B. Ostřanský (ed.), Praha 2014, pp. 282.
} 
gatherings and other events. ${ }^{10} \mathrm{~A}$ higher social status of the members of the religious community with an immigrant family history is easily observable within the third generation. In accordance with changes in the needs of the communities as well as their better financial possibilities, they can approach a solution in the form of a new, purpose-build building. The selection of the locality is important not only due to the possibilities of transportation to the venue: the overall infrastructure of civic amenities of the given locality need to be taken into account. The creation of public space and its common use are significant factors within the discussions concerning the building of new purpose-built buildings with a mainly religious function. Communication among community representatives and, possibly, investors on one side and representatives of the local municipalities, political movements, and civic initiatives is of key relevance during the preparatory phase, during the construction itself as well as after the building is given into use. ${ }^{11}$

The final shape of the space created mainly for religious purposes is the result of internal and external influences. The internal ones include the changes of the size and structure of the communities: the growing number of community members and the natural representation of several generations within its circles present a growing demand for suitable rooms. The shapes of the specific spaces reflect the general technical requirements influencing the preferred course of the gatherings, for instance the accessibility and navigability of the place, suitable sound and light conditions, as well as rentable energy efficiency while maintaining a comfortable temperature within the premises. ${ }^{12}$ Further inner requirements include regulations inspired by the normative form of the religion, since the space reflects the regular as well as the irregular rituals conducted within its limits by the entire community or its specific part. It points at the inner divisions within the community depending on age and/or sex. ${ }^{13}$ Furthermore, the lived forms of the religion become reflected in a form inspired by a given specific cultural interpretation. This motive is of key relevance for the final shape of the interior as well as the exterior of the building. Basic technical solutions based on current construction methods are supplemented by the application of various constructional elements with practical functions as well as symbolic ones. ${ }^{14}$ Thus the final shape of the building is created by a number of details complementing each other. These can be studied for instance within the decorations of gathering halls, technical spaces, or other specific parts of the given buildings.

One of the most relevant external factors influencing mainly the exterior of the buildings built for the purpose of religious gatherings are the local building

${ }^{10}$ Ch. Welzbacher, Euroislam Architektur. Die neuen Moscheen des Abendlandes, Amsterdam 2008, pp. 46-60.

${ }^{11}$ R. Zemke, Die Moschee als Aufgabe der Stadtplanung. Städtebauliche, baurechtliche und soziale Aspekte zur Integration des islamischen Gotteshauses in die Stadt und Ihre Gesellsachft. Eine Handlungsleifaden für Planer, Architekten und Bauherren, Berlin 2007, pp. 188-215, 235-237.

${ }_{12}$ J. Vaverka, Technické aspekty interiérů, [in:] Nové kostely a kaple z konce 20. století v České republice, J. Vaverka (ed.), Brno 2001, pp. 228-262.

${ }^{13}$ I. Serageldin, Backgroud Study, [in:] Architecture of the Contemporary Mosque, I. Serageldin, J. Steele (eds.), London 1996, pp. 8-11.

${ }^{14}$ N. Avc1oğlu, Identity-as-Form: The Mosque in the West, "Cultural Analysis" 2007, vol. 6, pp. 91-112. 
regulations. In this case they are a part of a general regulation of the technical standards applied during the construction of buildings with a specific purpose. Fire and security regulations are relevant as well, since they influence the technical details of the appearance of the interior and enhance its safety. The entire issue becomes even more serious for the local municipality, since these premises are usually visited by a high number of people. The regulation of the location of the building and the regulation of the significant elements influencing its external design are among the few effective means which the municipality can apply in these cases: the accordance of the project with the local territorial planning documentation is examined already before the issuance of the building permit. ${ }^{15}$ However, the effect of the future use of the proposed building is highly relevant as well and this is the issue which frequently becomes the subject of public debates. Communication with the local population often points at complaints concerning heightened levels of noise in urban areas, short-term problems with parking and the overall unsuitability of the setting of the building within the given area. In some cases the purpose of the building leads to an intercultural conflict. In other ones a fully open communication becomes established among the partners from the beginning. ${ }^{16} \mathrm{~A}$ comparison with the issue of building modern churches as parts of multifunctional complexes of buildings within the development of the infrastructure of residential areas shows a more general aspect of such issues. ${ }^{17}$

The establishment of cemeteries or their specialised parts is directly connected to the building of spaces with a predominantly religious function. In the case of the Muslim communities in Germany specifically designated sections of public cemeteries are used. A unique exception is the oldest part of the Islamic cemetery at Columbiadamm in Berlin, which is one of the topics presented in this paper. Usually Muslims of various ethnicities and claiming adherence to various branches of Islam are buried at the same cemetery field, which thus becomes an intriguing reflection of the history and diversity of the local Muslim population. ${ }^{18}$

The operation of these special spaces is influenced especially by German law, Islamic regulations as well as various forms of lived religion. ${ }^{19}$ Normative principles of Islam have traditionally been pursued mainly by Islamic organisations within the German context. ${ }^{20}$ These organisations operate on three basic levels: some of them

${ }^{15}$ R. Zemke, Die Moschee als Aufgabe der Stadtplanung. ..., op. cit., pp. 227-232.

${ }^{16}$ P. Kuppinger, Mosques and Minarets. Conflict, Participation, and Visibility in German Cities, “Anthropological Quarterly” 2014, vol. 87, no. 3, pp. 793-818.

${ }^{17} \mathrm{~J}$. Vaverka, Moderni sakrální stavby církvi a náboženských společností na území Čech, Moravy a Slezska, Brno 2004, pp. 195-198.

${ }^{18}$ Stressing one's adherence to a specific branch of Islam occurs only exceptionally within German cemeteries. However, we can encounter examples, such as the burial field in Hamburg-Ohlsdorf, which was established in 1941 as the result of an initiative of Iranian Shia tradesmen.

19 M. Klapetek, Umírání a smrt: Realizace náboženských pravidel..., op. cit., pp. 249-284. German law regulates cemeteries in Germany basically. Religious laws can complement them, if the state authorities allowed the opening of a cemetery owned by a religious community. I thank the anonymous reviewer for the comment.

${ }^{20}$ Experts associated with Theological institutes of several Universities have been voicing their opinions recently. Future developments will show their role within the development of the institutionalisation of Islam in Germany. 
perform their various activities within all parts of Germany; others focus only on one specific federal land; while associations with a merely local operation exist as well. ${ }^{21}$

However, this does not automatically mean that local associations have a minimal influence and that only organisations with a state-wide influence make all relevant decisions. German law has assigned competences concerning funerals from a federal level to the individual states and they have been carried further over to the level of individual municipal units. Therefore, examining this shift on the legal level means moving from the Constitution through laws to regional regulations and cemetery orders. the role of Muslim organisations is significant on the local level as well.

Expert solutions of the issues concerning funerals were adopted in federal states with higher proportions of Muslim population in the 1990s and a segment of professional funerary services businesses specialising on a Muslim clientele has developed. These companies offer complex services including the ritual cleaning of the body of the deceased, ${ }^{22}$ their dressing and the administration concerning the funeral.

However, this is not the only example of expert approaches towards the issues concerning the last journey of a person, since local Muslim organisations play the important role of partner in communication as an expert. Their statements influence the overall visual image of the specialised burial field dedicated to Muslims, such as its visual separation from other parcels, a different orientation of the graves and the erection of inner paths connecting the individual parts. In some cases public memorials, information boards, facilities for the ritual cleansing of the bereaved before conducting a given ritual and a desk for the display of the body of the deceased during the collective prayer are installed. ${ }^{23}$

Similarly to other activities of Muslim associations, a double level of their work is manifested. First, their cooperation with the municipality complements the offer of activities aimed primarily at the members of the association and their family members. Second, this process leads to the supervisory role of organised Islam, which thus enforces its approach towards individualised Muslims and persons with a Muslim cultural background. ${ }^{24}$ Therefore, the role of institutionalised Islam symbolically strengthens in the eyes of the media, the public, and the experts.

${ }^{21}$ The cemetery at Columbiadamm is an exception: It was given by Prussia to the Ottoman Empire and is now owned by the Republic of Turkey. Here and there in Germany are negotiations on the way between Muslim organisations and the responsible state agencies to confer to a Muslim institution the right to run a cemetery. So, all so-called Islamic cemeteries are specific areas in a cemetery run by the municipality or a church, designated to Muslims and mainly providing the qibla, but no eternal rest and in most cases also no facilities for washing the dead body, etc. I thank the anonymous reviewer for the comment.

${ }^{22}$ Spaces for the ritual washing of the deceased can be found in some larger mosques. This is another motive connecting both topics of this paper.

${ }^{23}$ Rotenburg, Lower Saxony, can serve as an example. S. Lohmann, Mit Blick gen Mekka, "Friedhofskultur - Zeitschrift für das gesamte Friedhofswesen" 2011, vol. 101, no. 7, pp. 28-29.

${ }^{24}$ T. Sakaranaho, Religious Freedom, Multiculturalism, Islam, Leiden 2006, pp. 208-209. About $60 \%$ of all Muslims in Germany are connected to Islam only by their cultural and social background; $20 \%$ are individualised Muslims and the remaining 20\% are organised Muslims. Due to the influence of family members the activities of organised Islam reach $36 \%$ of the Muslim population. 


\section{Mosque and cemetery: Manifestations of the needs of the community and the differences in the public space}

Two common denominators might be stressed in the synthesis of the individual views of the institutionalisation. First, the construction of spaces dedicated to religious purposes and the creation of cemeteries with special regulations are an expression of the needs of the communities, which are being defined gradually in the long term. In the case of new, purpose-built mosques and some prayer rooms, provisional solutions are overcome. ${ }^{25}$ This process is directly linked to the need of regular gatherings, which do not have to be exclusively religious: educational and free-time activities focusing on various groups within the community also pose specific requirements on the use of the space. A permanent stay of a larger number of persons belonging to various generations is a final state which must be reached gradually by the community. The decorations of the interior are an important part of the construction of the identity of the community, which stems from a specific cultural interpretation of Islam, is enhanced by the growing community and given down to the new generations. ${ }^{26}$

The establishment of specialised sections for Muslims at local cemeteries is also an expression of the needs of the communities. Again, this process requires a longer time during which an infrastructure focusing especially on the specific needs of Muslims is created. This structure does not focus solely on the solution of acute problems stemming in the temporality of the given person's stay in Germany. On the contrary, it is a reflection of the process of integration within the highly stratified majority population..$^{27}$ This process becomes visible on the general level of an association and the establishment of a burial field, yet, as the following text will show, the field research may move on more detailed level and focus on the parts of the grave observable above the ground level. In such case the researcher works with a specific understanding of religion and its lived cultural traditions. Furthermore, the influence of the family and friends of the deceased manifest in the final image of the grave. The establishment of a grave in Germany is not only a reflection of previous wishes of the deceased or the current financial situation of his family, but also an expression of the relations of a given immigrant family with the surroundings where next generations have already grown up..$^{28}$

Second, both the construction of spaces with mainly religious purposes and the establishment of cemeteries with specialised regulations present a visual construction

${ }^{25}$ The need of using provisional spaces can be reflected during prayers (salat) and the consequent social gatherings during the month of Ramadan (ifțar). A higher interest in the activities of Islamic organisations is observable among persons with a Muslim cultural background during this period.

${ }^{26}$ For connection with the theory of social capital, see K. Day, Exploring an Urban Ecology Visually: Spatial Approaches to Studying Social Contrasts along Germantown Avenue, [in:] Seeing Religion. Toward a Visual Sociology of Religion, R.R. Williams (ed.), New York 2015, pp. 38-41.

${ }^{27}$ M. Klapetek, Muslim Areas at Municipal Cemeteries in Germany and Austria, "Studia Religiologica” 2017, vol. 50, no. 3, p. 218.

${ }^{28}$ R. Benninghaus, Einige Aspekte islamischer Gräber und Gräberfeld in Deutschland - Ein Fotobericht, [in:] Muslime in deutscher Erde. Sterben, Jenseitserwartung und Bestattung, R. Sörries (ed.), Kassel 2009, pp. 37-55. 
of "otherness" in public space. This otherness is reflected in two main ways. First, the community begins to communicate in a more general way with the non-Muslim majority. The society first tends to ignore the differences among various mosque associations and is unable to differentiate among the specifics of the material displays of the funeral culture. The differences in both cases originate in the ethnic and cultural context which the community has brought over from its country of origin (e.g., Turkish or Bosnian Sunnis, Iranian Shias, Pakistani Ahmadiyas, and others). Various Sunni and Shia communities are first defined under the general umbrella term "Islamic." This primary generalisation naturally derives from evaluative comparison: to define "us," the carrier of the term "them" needs to be stated. Taking a stance towards otherness strengthens the culture of the non-Muslim majority society. ${ }^{29}$ Although the upcoming period of everyday life as well as extraordinary situation influence this relationship: the previous judgements can be affirmed and preserved, which, from the viewpoint of acculturation, poses the threat of the separation of the Muslim community or its marginalisation by the majority population. Another possibility is the overcoming of mutual prejudice and the beginning of a successful process of integration of individuals, families, as well as the entire group into the majority population. In such a case the buildings of mosques as well as the material evidence of funerary culture can become a proof of the religious, ethnic, and cultural diversity of the population of the city.

Moreover, the community presents its "otherness" in a more specific manner towards other local associations which are representatives of other cultural interpretations of Islam. The individual architectonic designs of mosques are an expression of a natural rivalry among the individual associations. Their leadership often requires clearly identifiable traditional architectonic elements to be included in the projects of new mosques which are supposed to invoke a nostalgic feeling. Such a design is supposed to support the mobilisation of the members of the community and thus define mutual cultural and religious differences..$^{30}$ As mentioned above, in the case of funerary culture, more than the general social level of the association is to be observed. According to the author, various Muslim graves within one section of a cemetery can present an opportunity for mutual communication among individuals as well as families. Permanent facilitators of communication include the design of the parts of the graves located above ground level and, in later phases, their decoration in the form of various memorabilia and flowers as well. An individualised result is created by a combination of details merging Orientalising aesthetics with elements of the local funerary culture.

Similarly to the case of the needs of a community, in this case the length of the process plays an important role as well. A constant proof of the visual presence of the "other" in public space is being created especially due to newly-built mosques and cultural centres. The case of creating tombstones in sections of public cemeteries

29 J. Waardenburg, Religionen und Religion. Systematische Einführung in die Religionswischenft, Berlin 1986, pp. 109-111.

${ }^{30}$ E. Roose, The Myth of the Orientalist Mosque. Towards an Iconography of Islamic Architecture in the Netherlands, "Canadian Journal of Netherlandic Studies" 2012/2013, no. 2/1, pp. 83-106. 
dedicated specifically to Muslims plays a similar role. The normative regulations of Islam emphasise the durability of the place of one's final rest and the prolongation of the rent of a burial spot is one of the most frequent problems among the administrator of a cemetery and the bereaved renting the spot. ${ }^{31}$

\section{Islamic cemetery at Columbiadamm and other alternatives}

Berlin is one of the key localities for the research of the institutionalisation of Islam in Germany. The city has undergone a turbulent development in the past one hundred and fifty years, while Muslims with a Turkish cultural background have been a part of its cosmopolitan environs.

The Islamic cemetery at Columbiadamm was established in 1866 and is a part of the Neuen Garnisonfriedhofs area. Emperor Wilhelm I dedicated the new burial area to the community of Turkish diplomats residing in Berlin. The most spectacular monument invoking the original shape of the cemetery is an obelisk from $1867 \mathrm{com}$ memorating the alliance between the Emperor's Germany and the Ottoman Empire. ${ }^{32}$ A pillar combining the red and yellow colours in a spiral stands on a tall pedestal with old tombstones. There is a gilded crescent on its top. During WWI the cemetery was used to bury Turkish soldiers who died as a result of war injuries despite the treatment they had received. ${ }^{33}$

After the fall of the Ottoman Empire the Turkish Ministry of Defence became the owner of the cemetery and its administration was undertaken by the employees of the Turkish Embassy. ${ }^{34}$ Thus the land area of the cemetery became extended in 1921 by further parcels. However, the area of the nearby Tempelhof airport needed to be extended in 1938 and, therefore the original Orientalising gate of the cemetery built in "Moorish style" was removed..$^{35}$ After 1945 the capacity of the oldest part of the cemetery was exhausted. From the original 220 graves 150 were preserved until the present day; the last burial took place here in 1989.

The situation required a solution and in the upcoming decades several new opportunities for a partial fulfilment of the normative Islamic regulations were created. The first alternative were burials in the neighbourhood, at the Islamic sections of the

${ }^{31}$ G. Kokkelink, Islamische Bestattung auf kommunalen Friedhöfen, [in:] In fremder Erde. Zur Geschichte und Gegenwart der islamischen Bestattung in Deutschland, G. Höpp, J. Gerdien (eds.), Berlin 1996, pp. 71-72; Y. Karakaşoğlu, Die Bestattung von Muslimen in der Bundesrepublik aus der Sicht türkisch-islamischer Organisationen, [in:] In fremder Erde..., op. cit., pp. 88-89.

32 R. Sörries, Von Mekka bis Berlin. Archäologie und Kulturgeschichte des islamischen Friedhofs, Wiesbaden 2015, p. 144.

33 This is the reason why the expression "Martyr" appears in the name of the mosque. The more down-to-earth expression "Turkish Military Cemetery" is also used.

34 G. Kokkelink, Islamische Bestattung..., op. cit., p. 70.

${ }_{35}$ G. Höpp, Tod und Geschichte oder Wie in Berlin prominente Muslime bestattet wurden, [in:] In fremder Erde. Zur Geschichte und Gegenwart der islamischen Bestattung in Deutschland, G. Höpp, J. Gerdien (eds.), Berlin 1996, p. 33. 
Neuen Garnisonfriedhofs ${ }^{36}$ Cemetery. This cemetery was originally a military one and has been extended several times. Currently a set of various burial fields can be found here: soldiers from the 1866, 1870-1871, and 1914-1918 war years are buried here alongside residents of the Neukölln district and Muslims from all over Berlin. It is not possible to extend the capacities of this cemetery, despite repeated efforts of the manager of the Islamic section. ${ }^{37}$

Another option was setting up new sections at Landschaftsfriedhof Gatow in Spandau district, where burials have been taking place since $1988 .{ }^{38}$ This is an extensive landscape-style cemetery. The locality is rather distant from districts with a higher proportion of Muslim inhabitants, yet the burial field for Muslims is set out on a separate parcel where no burials have taken place before. The number of sections designated for Muslims has repeatedly been raised. A simple infrastructure for the ritual cleansing of the believers conducting collective prayers for the deceased can be found here..$^{39}$ The third alternative, existing from 2015, are sections for Muslims at the Evangelical Neuen Zwölf-Apostel-Friedhof cemetery at Tempelhof-Schönberg district. So far the newest option is the Ruhleben cemetery in Charlottenburg-Wilmersdorf, where Muslims have been buried since 2016. The number of sections dedicated to Muslim graves might be extended in the future. ${ }^{40}$

\section{Şehitlik Mosque as an example of a nostalgic building}

The Mosque of Martyrs is located within the area of the Islamic cemetery at Columbiadamm, in a building which was originally built in Orientalising style in 1921$1922 .{ }^{41}$ In 1984-1985 the existing building was extended to a provisional prayer room with a cupola. ${ }^{42}$ This set of buildings has been systematically reconstructed in the past years. ${ }^{43}$ This process ensured that the entire space has become an architectonic expression of the representative intentions of the benefactor. Along this factor

${ }^{36}$ The cemetery was extended in 1963 and the first burials were conducted in 1976. R. Sörries, Von Mekka bis Berlin..., op. cit., p. 144.

${ }^{37}$ After the results of the referendum were announced, a solution of the situation was introduced by Neukölln District, which proposed to create an entirely new area within the Lilienthalstraße cemetery to be opened in 2018.

38 Y. Chaï, Der Status des Todes in der Migration, [in:] In fremder Erde. Zur Geschichte und Gegenwart der islamischen Bestattung in Deutschland, G. Höpp, J. Gerdien (eds.), Berlin 1996, p. 152.

${ }^{39}$ In some cases the collective prayers for the dead are conducted in the Mosque of Martyrs in Neukölln and the body is then transported to Spandau. M. Klapetek, Muslim Areas at Municipal Cemeteries in Germany and Austria, ..., op. cit., p. 217.

${ }^{40}$ This paper does not reflect opening of a new cemetery section at municipal cemetery in Neukölln. It will be dealt with in my future book. I thank the anonymous reviewer for comments.

${ }^{41}$ R. Spielhaus, Organisationsstrukturen islamischer Gemeinden, [in:] Islamisches Gemeindeleben in Berlin, R. Spielhaus, A. Färber (eds.), Berlin 2006, p. 13.

${ }^{42}$ B. Beinhauer-Köhler, C. Leggewie, Moscheen in Deutschland. Religiöse Heimat und gesellschaftliche Herausforderung, Munich 2009, p. 13.

${ }^{43}$ D.I. Limon, Zeitgenössische Moscheen in Europa. Bd.2.1. Kultstätten der Muslime in Deutschland und in Österreich, Offenbach am Main 2012, pp. 139-142. 
the institutionalisation of the local community, which uses the building for religious, educational, social, and free-time activities, is observable as well.

The Mosque of Martyrs gained its present shape between 1999 and 2005. The benefactor and administrator of the building is the Türkisch-Islamische Union der Anstalt für Religion (DİTIB), one of the biggest Islamic organisations active in all of Germany. Its various activities are designed mainly for families with Turkish roots ${ }^{44}$ The mosque itself offers space for 1500 believers participating in regular prayers. The main prayer hall for men is complemented with galleries dedicated to women. The mosque is used mainly by Turkish-speaking Muslims residing in the districts of Neukölln and Kreuzberg. Bearing in mind the topic of this paper, it is necessary to mention that the area belonging to the mosque is used to conduct collective prayers for the deceased. ${ }^{45}$

The colourful decoration of the hall is in accordance with the traditional Ottoman patterns, yet the decorations combine the original Turkish ceramics and marble. ${ }^{46}$ The benefactor paid attention to small details which combine into a compact unit. The interior thus makes an impression on regular as well as occasional visitors. ${ }^{47}$

There is another spacious room in the cellar, used among other functions for prayers as well. Due to such layout the building is an extensive three-floor mosque, which was rather exceptional at the time of its building. It is built in accordance with the traditional Ottoman design developed in the sixteenth and seventeenth centuries. ${ }^{48}$ The attention of the visitor gets caught by the central cupola which is 17 meters high as well as the two slim minarets reaching the height of 33 meters.

An informational and cultural centre, built also in a nostalgic style, is also a part of the complex. ${ }^{49}$ These two main buildings have so far been complemented by less visually attractive provisory parts housing offices, lavatories, shops with religious items, literature, groceries, etc. This part shall undergo a significant reconstruction in the last phase of the project and, together with the cultural centre, shall create opposing wings leading towards the centre where the building of the mosque stands.

The expression "nostalgic building" appears mainly within the evolutional conception of the development of mosques in Europe. Experts assumed that the oldest mosques would be built in accordance with patterns and memories which the communities had brought from their countries of origin. The next expected phase would be the construction of hybrid mosques, which would reflect the gradually growing influence of integration into the new surroundings. This would present an inter-stage during which traditional decorative patterns would be eclectically combined with modern forms of architecture. After the integration of the community would be complete, the architecture of the new buildings would divert from its traditional forms

${ }^{44}$ M. Rohe, Der Islam in Deutschland..., op. cit., pp. 131-135.

${ }^{45}$ M. Klapetek, Umírání a smrt: Realizace náboženských pravidel..., op. cit., pp. 267-268.

${ }^{46}$ T. Wöhler, Neue Architektur. Sakralbauten, Salenstein 2005, p. 62.

${ }^{47}$ The mosque organises tours for the public as well as students and pupils. The local community regularly joins the Day of Open Mosques which takes place annually on 3 October as part of the statewide celebrations of The Day of German Unity.

${ }^{48}$ S. Blair, J. Bloom, The Art and Architecture of Islam, 1250-1800, New Haven 1995, pp. 213-230.

${ }^{49}$ The opening ceremony of the Center took place as recently as 2015. 
and lean towards modern ones. However, research in western Europe has proven this long-established evolutionist hypothesis wrong..$^{50}$ Around the year 2000 several new, purpose-built mosques were constructed which maintained the nostalgic exterior, or at least the interior, in various forms. Since the 1960s two generations of Muslims have been raised in Germany and, in accordance with the logic of the aforementioned hypothesis, the nostalgic approach towards the architecture of mosques should be receding more and more.

Thus the explanations of these developments need to be found elsewhere. The overall understanding of the building has recently not been explained as a direct proof of integration (modern buildings) or separation of the group (traditional architecture), but rather the maintaining of architectonic elements typical for a specific cultural interpretation of Islam is understood as an accentuation of the uniqueness of the community.

The evolutionist approach towards the integration/assimilation process paid maximum attention to the expected changes of relations among the community and the majority population. However, the current situation has shown that the complicated integration to a naturally structured society requires another difficult process: the definition of the mutual relations among the various individual cultural interpretations of Islam, which have been functioning side by side within one European country.

\section{Conclusion}

The author of the present paper assumes that the issue of the construction spaces dedicated mainly to religious purposes and that of the creation of specialised sections for Muslims at public cemeteries can be connected into one subject of research. Such approach consequently enables the researcher to study mutual connections and reach more general results. In the case of new buildings, multi-functionality needs to be stressed in accordance with the structure of the community. The final conception of the building is a result of different influences. In the case of the establishment of burial fields, the processes of expert solutions are worth to observe, especially cooperation of Islamic organizations and owners of cemeteries. The topic of funerary services, however, includes the whole spectrum of the Muslim population of Germany. Therefore, the role of organised Islam within the entire picture needs to be precisely analysed. In this case space for the application of anthropological methods into the research of Religious studies is created. Furthermore, the issue of the permanent, or at least long-term, construction of "otherness" within the European public space arises. Comparative Religious studies can analyse the outcomes of the research of Muslim communities and compare them with further examples from another world

${ }^{50}$ E. Roose, Mosque Design and Muslim Patrons in the Netherland. The Quest for the Ultimate Islamic Construction, [in:] The Mosque: Political, Architectural and Social Transformations, E. Erkoçu, C. Buğdac1 (eds.), Rotterdam 2009, p. 116. 
religions. In this case the context of specific situations can be abandoned, and the issue may be reviewed from the distance of a more general level. ${ }^{51}$

The complex of buildings around the Mosque of Martyrs is an interesting example of the architectonic expression of the institutionalisation of an important community with a Turkish cultural background. ${ }^{52}$ Due to the implemented architectural motifs, the costly reconstruction of provisory objects is a manifestation of the uniqueness of a specific cultural interpretation of Sunni Islam which has been developed gradually. The research of the architecture of mosques established by the DİTiB shall require the comparison of several further relevant objects. Despite the fact that they were constructed within the time frame of less than twenty years, the leadership of the individual communities has opted for varying designs of the buildings, their technical aspects as well as decorations. ${ }^{53}$

The oldest part of the Islamic cemetery at Columbiadamm together with specialised sections at Neuen Garnisonfriedhofs are a relevant evidence of the history of funerary culture from the second half of the nineteenth century up to the present day. Despite the prevailing Turkish design, the graves are a proof of the diversity of the Muslim population of Berlin. The integrational potential of the funerals in Germany has also been reflected in the development of further possibilities offered by presentday Berlin.

These two examples illustrate the interconnection between the needs of a particular segment of the population and the manifestation of uniqueness in public space - and that was the aim of the paper. From my point of view, the described empirical case is interesting in general. Firstly, the social processes last long period in comparison to other localities in Germany. Secondly, this situation is paradoxically exceptional throughout Germany. The empirical case is bordering almost the ideal type in sociological meaning with its complexity. I find the founding of both cemeteries and mosques as one of the crucial motives in institutionalization of Islam. Both topics show the same: There must be defined aspace for the future activities' development. ${ }^{54}$

In the case of the research of the construction of mosques and the creation of sections for Muslims at public cemeteries, Comparative Religious studies can first use examples from the religious history of Europe. Furthermore, the analysis of the current results of the research of the institutionalisation of Islam which has been ongoing for the past decades needs to be taken into account. Moreover, it is necessary to observe the mid-term and long-term effects of the so-called refugee crisis. However, a complex image is achievable only if the effects of the migration on the Muslim

51 The urgency of the current situation enhances the false impression that this is an utterly exceptional case of confrontation with a carrier of "otherness." However, long-term researches of Post-Colonial studies show that the key to understanding the connections is the meta-level of the narrated story.

52 This realization shows a complexity of situation: The cemetery is managed by the Turkish embassy, but the mosque itself is kept by DITIB. I thank the anonymous reviewer for the comment.

${ }^{53}$ The following buildings can be included among the researched ones: Fatih Moschee (1992, Pforzheim), Hicret-Moschee (1996, Launingen/Donau), Yavuz Sultan Selim Moschee (1995, Mannheim), Merkez Moschee (2008, Duisburg), as well as Zentral-Moschee (2017, Köln).

${ }^{54}$ In the case of Islamic cemeteries one of the special concerns is the ban on cremation. I thank the anonymous reviewer for the comment. 
population as well as on the majority are analysed. In such a case the issues concerning Islam can become an important part of the discussion about the processes of secularisation and deprivatisation of religion in Europe. ${ }^{55}$

\section{References}

75 Jahre iranisch-islamisches Gräberfeld in Hamburg-Ohlsdorf: X-19, Kapelle 2: 1941-2016, V. Firouz (ed.), Hamburg 2016.

Avcioğlu N., Identity-as-Form: The Mosque in the West, "Cultural Analysis" 2007, vol. 6, pp. 91 112.

Baumann M., Temples, Cupolas, Minarets: Public Space as Contested Terrain in Contemporary Switzerland, "Religio" 2009, vol. 17, no. 2, pp. 141-153.

Beinhauer-Köhler B., Von der unsichtbaren zur sichtbaren Religion. Räume muslimischer Glaubenspraxis in der Bundesrepublik, "Zeithistorische Forschungen" 2010, vol. 7, no. 3, pp. $408-430$.

Beinhauer-Köhler, B., Leggewie, C., Moscheen in Deutschland. Religiöse Heimat und gesellschaftliche Herausforderung, Munich 2009.

Benninghaus R., Einige Aspekte islamischer Gräber und Gräberfeld in Deutschland - Ein Fotobericht, [in:] Muslime in deutscher Erde. Sterben, Jenseitserwartung und Bestattung, R. Sörries (ed.), Kassel 2009, pp. 37-55.

Blair S., Bloom J., The Art and Architecture of Islam, 1250-1800, New Haven 1995.

Day K., Exploring an Urban Ecology Visually: Spatial Approaches to Studying Social Contrasts along Germantown Avenue, [in:] Seeing Religion. Toward a Visual Sociology of Religion, R.R. Williams (ed.), New York 2015, pp. 38-41.

Epstein-Mil R., Richter M., Die Synagogen der Schweiz. Bauten zwischen Emanzipation, Assimilation und Akkulturation, Zürich 2008.

Everyday Lived Islam in Europa, N.M. Dessing, N. Jeldtoft, J.S. Nielsen, L. Woodhead (eds.), Farnham 2013.

Höpp G., Tod und Geschichte oder Wie in Berlin prominente Muslime bestattet wurden, [in:] In fremder Erde. Zur Geschichte und Gegenwart der islamischen Bestattung in Deutschland, G. Höpp, J. Gerdien (eds.), Berlin 1996, pp. 19-44.

Chaïb Y., Der Status des Todes in der Migration, [in:] In fremder Erde. Zur Geschichte und Gegenwart der islamischen Bestattung in Deutschland, G. Höpp, J. Gerdien (eds.), Berlin 1996, pp. 147-158.

Chbib R., Organisations des Islams in Deutschland. Divärsität, Dynamiken und Sozialformen im Religionsfeld der Muslime, Baden-Baden 2017.

Karakaşoğlu Y., Die Bestattung von Muslimen in der Bundesrepublik aus der Sicht türkisch-islamischer Organisationen, [in:] In fremder Erde. Zur Geschichte und Gegenwart der islamischen Bestattung in Deutschland, G. Höpp, J. Gerdien (eds.), Berlin 1996, pp. 83-105.

Klapetek M., Muslim Areas at Municipal Cemeteries in Germany and Austria, "Studia Religiologica" 2017, vol. 50, no. 3, pp. 203-220.

Klapetek M., Synagoga, kostel, mešita... Architektura jako téma pro religionistiku, "Pantheon" 2013, vol. 8, no. 2, pp. 46-61.

${ }_{55}^{5}$ M. Klapetek M., Wzrost znaczenia islamu w Europie jako część procesu oddzielania się religii od kultury, "Theologos" 2017, vol. 19, no. 1, pp. 229-236. 
Klapetek M., Umírání a smrt: Realizace náboženských pravidel v nemuslimském prostředi, [in:] Smrt, hroby a záhrobí v islámu. Posledni věci člověka pohledem muslimských pramenů, B. Ostřanský (ed.), Praha 2014, pp. 249-284.

Klapetek M., Wzrost znaczenia islamu w Europie jako część procesu oddzielania się religii od kultury, "Theologos" 2017, vol. 19, no. 1, pp. 229-236.

Kokkelink G., Islamische Bestattung auf kommunalen Friedhöfen, [in:] In fremder Erde. Zur Geschichte und Gegenwart der islamischen Bestattung in Deutschland, G. Höpp, J. Gerdien (eds.), Berlin 1996, pp. 63-82.

Kuppinger P., Mosques and Minarets. Conflict, Participation, and Visibility in German Cities, "Anthropological Quarterly" 2014, vol. 87, no. 3, pp. 793-818.

Limon I. D, Zeitgenössische Moscheen in Europa. Bd.2.1. Kultstätten der Muslime in Deutschland und in Österreich, Offenbach am Main 2012.

Lohmann S., Mit Blick gen Mekka, "Friedhofskultur - Zeitschrift für das gesamte Friedhofswesen" 2011, vol. 101, no. 7, pp. 28-29.

Rohe M., Der Islam in Deutschland. Eine Bestandsaufnahme, Munich 2016.

Roose, E., Mosque Design and Muslim Patrons in the Netherland. The Quest for the Ultimate Islamic Construction, [in:] The Mosque: Political, Architectural and Social Transformations, E. Erkoçu, C. Buğdac1 (eds.), Rotterdam 2009, pp. 114-126.

Roose E., The Myth of the Orientalist Mosque. Towards an Iconography of Islamic Architecture in the Netherlands, "Canadian Journal of Netherlandic Studies" 2012/2013, no. 2/1, pp. 83-106.

Sakaranaho T., Religious Freedom, Multiculturalism, Islam, Leiden 2006.

Serageldin I., Background Study, [in:] Architecture of the Contemporary Mosque, I. Serageldin, J. Steele (eds.), London 1996, pp. 8-11.

Sörries R., Von Mekka bis Berlin. Archäologie und Kulturgeschichte des islamisches Friedhofs, Wiesbaden 2015.

Spielhaus R., Organisationsstrukturen islamischer Gemeinden, [in:] Islamisches Gemeindeleben in Berlin, R. Spielhaus, A. Färber (eds.), Berlin 2006, pp. 12-17.

Stark R., How New Religions Succeed: A Theoretical Model, [in:] The Future of New Religious Movements, D.G. Bromley, Ph.E. Hammond (eds.), Macon 1987, pp. 11-27.

Vaverka J., Moderní sakrální stavby církví a náboženských společností na územi Čech, Moravy a Slezska, Brno 2004.

Vaverka J., Technické aspekty interiérů, [in:] Nové kostely a kaple z konce 20. století v České republice, J. Vaverka (ed.), Brno 2001, pp. 228-262.

Waardenburg J., Religionen und Religion. Systematische Einführung in die Religionswischenft, Berlin 1986.

Welzbacher Ch., Euroislam Architektur. Die neuen Moscheen des Abendlandes, Amsterdam 2008.

Wöhler T., Neue Architektur. Sakralbauten, Salenstein 2005.

Yearbook of Muslims in Europe, O. Scharbrodt, S. Akgönül, A. Alibašić, J.S. Nielsen, E. Račius (eds.), Leiden 2018, vol. 9.

Zemke R., Die Moschee als Aufgabe der Stadtplanung. Städtebauliche, baurechtliche und soziale Aspekte zur Integration des islamischen Gotteshauses in die Stadt und Ihre Gesellsachft. Eine Handlungsleifaden für Planer, Architekten und Bauherren, Berlin 2007. 
